\title{
CEREBELLAR EXCITATORY AMINO ACID BINDING SITES IN NORMAL, GRANULOPRIVAL, AND PURKINJE CELL-DEFICIENT MICE
}

\author{
R. L. Makowiec, J. J. Cha, J. B. Penney and A. B. Young* \\ Neuroscience Program and Department of Neurology, University of Michigan, 1103 East Huron, \\ Ann Arbor, MI 48104-1687, U.S.A.
}

\begin{abstract}
Using quantitative autoradiography, the cellular localization and characterization of cerebellar excitatory amino acid binding sites in normal, Purkinje cell-deficient and granuloprival (granule cell-deficient) mouse cerebella were investigated. In the molecular layer of normal mouse cerebellum, the quisqualate subtype of excitatory amino acid receptor (assayed by $\left[{ }^{3} \mathrm{H}\right](R S)$ )- $\alpha$-amino-3hydroxy-5-methylisoxazole-4-propionate, quisqualate-sensitive $\mathrm{L}-\left[{ }^{3} \mathrm{H}\right]$ glutamate, and $\left[{ }^{3} \mathrm{H}\right] 6$-cyano-7-nitroquinoxaline-2,3-dione binding) predominated. In the granule cell layer of the cerebellum, $N$-methyl-Daspartate-sensitive $\mathrm{L}-\left[{ }^{3} \mathrm{H}\right] \mathrm{glutamate}$ and $\left[{ }^{3} \mathrm{H}\right] \mathrm{glycine}$ binding sites were predominant.

In the molecular layer of Purkinje cell-deficient mutant mice, $\left[{ }^{3} \mathrm{H}\right](R S)-\alpha$-amino-3-hydroxy-5methylisoxazole-4-propionate binding sites and $\left[{ }^{3} \mathrm{H}\right] 6$-cyano-7-nitro-quinoxaline-2,3-dione binding were reduced to $24 \%(P<0.01)$ and $36 \%(P<0.001)$ of control, respectively, while quisqualate-sensitive $\left[{ }^{3} \mathrm{H}\right] \mathrm{glutamate}$ binding sites were reduced to $54 \%$ of control $(P<0.01) . N$-Methyl-D-aspartate-sensitive $\left[{ }^{3} \mathrm{H}\right]$ glutamate and $\left[{ }^{3} \mathrm{H}\right]$ glycine binding were unchanged. In the granule cell layer of these mouse cerebella, there was no change in excitatory amino acid receptor binding.

In the molecular layer of granuloprival mouse cerebella, $\left[{ }^{3} \mathrm{H}\right](R S)$ - $\alpha$-amino-3-hydroxy-5-methylisoxazole-4-propionate binding was increased to $205 \%$ of control $(P<0.01),\left[{ }^{3} \mathrm{H}\right] 6$-cyano-7-nitro-quinoxaline2,3-dione binding was increased to $136 \%$ of control $(P<0.02)$, and quisqualate-sensitive [ $\left.{ }^{3} \mathrm{H}\right]$ glutamate binding was increased to $152 \%$ of control $(P<0.01)$. N-Methyl-D-aspartate-sensitive $\left[{ }^{3} \mathrm{H}\right]$ glutamate and $\left.{ }^{3} \mathrm{H}\right]$ glycine binding were unchanged. In areas of granule cell depletion $N$-methyl-D-aspartate-sensitive $\left[{ }^{3} \mathrm{H}\right]$ glutamate and $\left[{ }^{3} \mathrm{H}\right]$ glycine binding were reduced to $68 \%(P<0.01)$ and $59 \%(P<0.01)$ of control, respectively. In the granule cell layer, binding to quisqualate receptors was not significantly different from binding in controls with any of the ligands tested.

These results suggest that three different receptor assays: $\left[{ }^{3} \mathrm{H}\right](R S)-\alpha$-amino-3-hydroxy-5-methylisoxazole-4-propionate, quisqualate-sensitive $\mathrm{L}$ - $\left[{ }^{3} \mathrm{H}\right]$ glutamate, and $\left[{ }^{3} \mathrm{H}\right] 6$-cyano-7-nitro-quinoxaline-2,3-dione binding can be used to demonstrate that quisqualate receptor specific binding sites are located on Purkinje cell dendrites in the molecular layer of cerebellum, and that these binding sites apparently up-regulate in response to granule cell ablation and Purkinje cell deafferentation.
\end{abstract}

Glutamate is a major excitatory neurotransmitter in the mammalian central nervous system. ${ }^{8,45}$ Electrophysiological evidence indicates that the excitatory action of glutamate is mediated by at least three subtypes of ion channel-linked ("ionotropic") receptors named according to the agonists which preferentially excite them: $N$-methyl-D-aspartate (NMDA), quisqualate, and kainate. ${ }^{9}$ In addition, a new type of glutamate receptor, a quisqualate-preferring "metabotropic" receptor, linked to inositol phospholipid metabolism has been reported. ${ }^{42,44}$ The anatomic distribution and pharmacological characterization of the glutamate ionotropic receptor subtypes in brain sections can be studied. $\left.{ }^{14,15,31} \mathrm{~L}-{ }^{3} \mathrm{H}\right]$ Glutamic acid and selective incubation conditions have been used to

-To whom correspondence should be addressed.

Abbreviations: AMPA, (RS)- $\alpha$-amino-3-hydroxy-5-methylisoxazole-4-propionate; CNQX, 6-cyano-7-nitroquinoxaline-2,3-dione; EAA, excitatory amino acid; KSCN, potassium thiocyanate; MAM, methylazoxymethanol; NMDA, $N$-methyl-D-aspartate. measure "quisqualate-sensitive" binding sites in brain. ${ }^{4}$ These methods, however, may measure both the ionotropic and metabotropic quisqualatesensitive receptors. The ionotropic quisqualate receptor appears to be labeled selectively by $\left[{ }^{3} \mathrm{H}\right](R S)$ $\alpha$-amino-3-hydroxy-5-methylisoxazole-4-propionate $\left(\left[{ }^{3} \mathrm{H}\right] \mathrm{AMPA}\right){ }^{20,33,34}$ The NMDA receptor can be measured with a variety of ligands that bind to the neurotransmitter binding site (e.g. glutamate) or to modulator sites (e.g. glycine and MK-801).,29

The cerebellar cortex is a convenient region in which to study excitatory amino acid (EAA) receptors because the cerebellar neuronal circuitry is well understood. ${ }^{23,30}$ Extensive morphological and neurochemical evidence supports a neurotransmitter function for L-glutamate at afferent mossy fiber terminals $1,10,12$ and intrinsic granule cell/parallel fiber synapses, ${ }^{22,26,40}$ and for L-aspartate at afferent climbing fiber-Purkinje cell synapses. ${ }^{39,46}$ Thus, cerebellar Purkinje cells receive EAA input from both the climbing fibers and the granule cell/parallel fiber system, while the granule cells receive such input from 
the mossy fibers. Selective mutations and cytotoxic drug treatments alter cerebellar circuitry by rendering the cerebellum deficient in specific cell types. ${ }^{24,43}$ The pharmacological evidence for the multiplicity of EAA receptors underscores the importance of identifying the specific EAA receptor subtypes mediating neuronal transmission in the cerebellar cortex. Previous work in our laboratory by Olson et al. ${ }^{36}$ suggested that quisqualate-sensitive binding sites are located principally on dendrites of Purkinje cells and that they up-regulate after deafferentation. Advances in EAA research have led to the development of several new ligands specific for the ionotropic quisqualate receptor. AMPA has been described as a potent and selective agonist of the ionotropic quisqualate receptor and the compound has been radiolabeled. ${ }^{20,34}$ Studies using $\left[{ }^{3} \mathrm{H}\right] \mathrm{AMPA}$ have been difficult to interpret due to the presence of both high and low affinity binding sites. ${ }^{19.33}$ Recently, a relatively selective antagonist, 6-cyano-7-nitro-quinoxaline-2,3-dione (CNQX), of quisqualate- or AMPA-induced responses has been developed. In binding studies CNQX has been shown to bind with a single affinity to both the high and low affinity AMPA binding sites. ${ }^{35}$ The purpose of this study was to use normal, granuloprival, and Purkinje cell-deficient mice to determine the cellular localization and regulation of the ionotropic quisqualate-sensitive binding sites by means of quantitative receptor autoradiography using the selective radioligands $\left[{ }^{3} \mathrm{H}\right] \mathrm{AMPA}$ and $\left[{ }^{3} \mathrm{H}\right] \mathrm{CNQX}$.

\section{EXPERIMENTAL PROCEDURES}

\section{Materials}

L- ${ }^{3} \mathrm{H}$ Glutamate (specific activity $46-53 \mathrm{Ci} / \mathrm{mmol}$ ) and $\left[{ }^{3} \mathrm{H}\right]$ glycine $(19 \mathrm{Ci} / \mathrm{mmol})$ were obtained from Amersham (Arlington Heights, IL). [ $\left.{ }^{3} \mathrm{H}\right](R S)-\alpha$-Amino-3-hydroxy-5methylisoxazole-4-propionate $\left(\left[{ }^{3} \mathrm{H}\right] \mathrm{AMPA} ; 28-29 \mathrm{Ci} / \mathrm{mmol}\right)$ was obtained from New England Nuclear (Boston, MA) and CNQX $(5.5 \mathrm{Ci} / \mathrm{mmol})$ with a chemical purity $\geq 97 \%$ and a radiochemical purity $\geq 98 \%$ was synthesized by Chemsyn Science Laboratories (Lenexa, KA). Non-radioactive AMPA, NMDA, and quisqualate were obtained from Cambridge Research Biochemicals (Valley Stream, NY). Calcium chloride $\left(\mathrm{CaCl}_{2}\right)$ was obtained from Fisher (Fairlawn, NJ). All other compounds were purchased from Sigma (St Louis, MO).

\section{Animals}

Homozygous recessive "nervous" mutant mice (nr/nr) which are $90 \%$ deficient in Purkinje cells were obtained from Jackson Laboratories (Bar Harbor, ME). ${ }^{41}$ Neurologically normal littermates $(\mathrm{nr} /+)$ served as controls. Binding experiments were performed in 42-day-old mice. Granuloprival mice were produced by injecting pups of male CD-1 mice from Charles River Labs (Wilmington, MA) with methylazoxymethanol (MAM, $30 \mathrm{mg} / \mathrm{kg}$ diluted to a concentration of $10 \mathrm{mg} / \mathrm{ml}$ in $0.9 \% \mathrm{NaCl}$ ) subcutaneously within $4 \mathrm{~h}$ of birth. MAM is a nucleic acid alkylating agent which kills cells undergoing mitosis at the time of drug distribution. When injected on postnatal day 1, MAM causes a depletion of granule, stellate, basket, and Golgi cells while sparing Purkinje cells in the mouse cerebellum. ${ }^{6,16,24.25}$ Binding experiments were performed in 42-day-old mice that had been treated as pups with MAM. Saline-injected littermates were used as controls.

\section{Tissue preparation}

Forty-two-day-old mice were decapitated and their brains were quickly removed. Cerebella were separated from forebrain, mounted on cryotome pedestals with Lipshaw embedding matrix, and frozen under powdered dry ice. The frozen cerebella were cut into $20 \mu \mathrm{m}$ sections at $-20^{\circ} \mathrm{C}$ on a Lipshaw cryostat and thaw mounted onto gelatin-coated slides. Sections were stored for less than $24 \mathrm{~h}$ at $-20^{\circ} \mathrm{C}$. To remove endogenous ligands, all sections underwent a prewash for $30 \mathrm{~min}$ at $2^{\circ} \mathrm{C}$ in either $50 \mathrm{mM}$ Tris- $\mathrm{HCl}$ buffer $(\mathrm{pH}$ 7.20 ), $50 \mathrm{mM}$ Tris- $\mathrm{HCl}$ buffer containing $2.5 \mathrm{mM} \mathrm{CaCl}$ (pH 7.20), $50 \mathrm{mM}$ Tris- $\mathrm{HCl}$ buffer containing $2.5 \mathrm{mM}$ $\mathrm{CaCl}_{2}$ and $100 \mathrm{mM}$ potassium thiocyanate $(\mathrm{KSCN}, \mathrm{pH}$ 7.20 ), $50 \mathrm{mM}$ Tris-acetate buffer ( $\mathrm{pH} 7.40$ ), or $50 \mathrm{mM}$ Tris-citrate buffer ( $\mathrm{pH} 7.20$ ). Sections were blown dry under a stream of room temperature air. The buffer used in the prewash was always the same as that used in subsequent binding experiments, as described below.

\section{Autoradiography}

A detailed description of the method for glutamate receptor autoradiography has been published. . $^{1434}$ Briefly, "quisqualate-sensitive L- $\left[{ }^{3} \mathrm{H}\right]$ glutamate binding" was carried out at $2^{\circ} \mathrm{C}$ with $200 \mathrm{nM} \mathrm{L}-[3 \mathrm{H}]$ glutamate in $50 \mathrm{mM}$ Tris $-\mathrm{HCl}$ containing $2.5 \mathrm{mM} \mathrm{CaCl}$ and $100 \mu \mathrm{M} \mathrm{NMDA}$, and is defined as that binding which is displaced by $2.5 \mu \mathrm{M}$ quisqualate. $\left[{ }^{3} \mathrm{H}\right] \mathrm{AMPA}$ binding assays were carried out with $37 \mathrm{nM}\left[{ }^{3} \mathrm{H}\right] A M P A$ in $50 \mathrm{mM}$ Tris- $\mathrm{HCl}$ plus $2.5 \mathrm{mM}$ $\mathrm{CaCl}_{2}$ and $100 \mathrm{mM} \mathrm{KSCN}$. Non-specific binding was determined in the presence of $1 \mathrm{mM}$ unlabeled L-glutamate and represented less than $5 \%$ of total binding. For both $\left[{ }^{3} \mathrm{H}\right] \mathrm{AMPA}$ and quisqualate-sensitive $\mathrm{L}-\left[{ }^{3} \mathrm{H}\right]$ glutamate binding assays, sections were incubated for $45 \mathrm{~min}$ at $2^{\circ} \mathrm{C}$. For $\left[{ }^{3} \mathrm{H}\right] \mathrm{CNQX}$ binding, the tissue was incubated for $60 \mathrm{~min}$ with $64 \mathrm{nM}\left[{ }^{3} \mathrm{H}\right] \mathrm{CNQX}$ at $2^{\circ} \mathrm{C}$ in $50 \mathrm{mM}$ Tris-HCl. Nonspecific binding was determined in the presence of $1 \mathrm{mM}$ L-glutamate and represented less than $30 \%$ of total binding of $\left[{ }^{3} \mathrm{H}\right] \mathrm{CNQX}$. NMDA-sensitive $\mathrm{L}-\left[{ }^{3} \mathrm{H}\right]$ glutamate binding was carried out at $2^{\circ} \mathrm{C}$ with $200 \mathrm{nM} \mathrm{L-}\left[{ }^{3} \mathrm{H}\right]$ glutamate in $50 \mathrm{mM}$ Tris acetate buffer containing $2.5 \mu \mathrm{M}$ quisqualate. Non-specific binding was determined in the presence of $1 \mathrm{mM}$ NMDA and represented less than $20 \%$ of total binding. $\left[{ }^{3} \mathrm{H}\right]$ Glycine binding was carried out at $2{ }^{\circ} \mathrm{C}$ with $100 \mathrm{nM}\left[{ }^{3} \mathrm{H}\right]$ glycine in $50 \mathrm{mM}$ Tris-citrate buffer. Nonspecific binding was determined in the presence of $1 \mathrm{mM}$ unlabeled glycine and represented less than $5 \%$ of total binding. Saturation studies for $\left[{ }^{3} \mathrm{H}\right]$ AMPA $(2 \mathrm{nM}-3 \mu \mathrm{M})$ and quisqualate-sensitive $\mathbf{L}-\left[{ }^{3} \mathrm{H}\right]$ glutamate $(3 \mathrm{nM}-5 \mu \mathrm{M})$ were carried out in the presence of varying concentrations of unlabeled ligands.

After incubation with tritiated ligands, sections were rinsed quickly three times with cold buffer and then rinsed with cold $2.5 \%(\mathrm{v} / \mathrm{v})$ glutaraldehyde in acetone. The total rinse time was less than $10 \mathrm{~s}$. Sections were blown dry with warm air. Dried sections were placed in X-ray cassettes with appropriate radioactive standards ${ }^{37}$ and apposed to Amersham Hyperfilm. The film was exposed to the tissue sections for 14-21 days at $4^{\circ} \mathrm{C}$ and then developed, fixed, and dried Tissue sections were then postfixed with paraformaldehyde and stained with Cresyl Violet. Individual layers of cerebellum were identified on autoradiographs by comparison with the Cresyl Violet-stained sections of the same tissue producing the film image. The optical densities of the resultant film images were determined using a computer-assisted, video-based image analysis system (Imaging Research, St Catherines ONT, Canada). Twelve to 18 readings were averaged from each area of interest in triplicate sections. The radioactivity was determined by a computer-generated polynomial regression analysis that compared film densities 
produced by the tissue sections to those produced by the radioactive standards. All data presented were analysed densitometrically from autoradiographic images.

\section{Data analysis}

Binding to the molecular layer and granule layers of granuloprival mice was compared to that in saline-treated littermates. Similarly, binding in homozygous "nervous" mutant mice lacking Purkinje cells was compared to neurologically normal littermates. Scatchard analysis and the resulting $K_{d}$ and $B_{\max }$ values were resolved by the non-linear regression program LIGAND. ${ }^{32}$ Statistical analysis was by unpaired $t$-tests.

\section{RESULTS}

\section{Histology}

In normal cerebellum the granule cell layer is characterized by a very dense collection of cell nuclei. The Purkinje cell layer is a monolayer of large neurons with pale staining nuclei located between the granule cell layer and the molecular layer. The outer layer (molecular layer) has relatively few intrinsic neurons (basket and stellate cells), and the abundant neuropil consists largely of granule cell axons and Purkinje cell dendrites (Fig. 1A). In "nervous" mutant mice $(\mathrm{nr} / \mathrm{nr}$ ), there was a severe depletion of Purkinje cells. The granule cell layer had a normal cell density, whereas the molecular layer was thinner than normal (Fig. 1B). In the granuloprival (MAMtreated) mice, there was a marked depletion of granule cells in a patchy distribution. The damaged granule cell layer appeared wider than normal, but had a markedly decreased density of granule cell nuclei. The molecular layer was slightly narrower than in saline-treated controls but had no increase in the number of glial cell nuclei. Purkinje cells in these animals appeared normal (Fig. 1C).

\section{Nervous (Purkinje cell-deficient) mice and hetero- zygous controls}

In control $(\mathrm{nr} /+)$ mice $\left[{ }^{3} \mathrm{H}\right]$ AMPA binding sites (which label ionotropic quisqualate receptors) were 13 times as numerous in the molecular layer as they were in the granule cell layer (total $B_{\max }=36.2$ vs $2.7 \mathrm{pmol} / \mathrm{mg}$ protein; Figs $2 \mathrm{~A}$ and $3 \mathrm{~A}$ ). In the presence of $100 \mathrm{mM} \mathrm{KSCN}$, saturation studies of $\left[{ }^{3}\right.$ H]AMPA binding produced curvilinear Scatchard plots which fit a two-site model better than a one-site model $(P<0.001, F$-test as compared to a linear fit; Fig. 4). The curves in the control mice could be resolved into two binding sites with a high affinity component $K_{d}=10 \pm 4 \mathrm{nM}, B_{\max }=2.0 \pm 0.5$ $\mathrm{pmol} / \mathrm{mg}$ protein and a low affinity component $K_{d}=758 \pm 157 \mathrm{nM}, B_{\max }=34.2 \pm 3.4 \mathrm{pmol} / \mathrm{mg}$ protein. In the molecular layer of "nervous" mutants, $\left[{ }^{3} \mathrm{H}\right]$ AMPA saturation studies again yielded curvilinear Scatchard plots with a high affinity component $K_{d}=33 \pm 14 \mathrm{nM}, B_{\max }=2.2 \pm 1.0 \mathrm{pmol} / \mathrm{mg}$ protein, and a low affinity component $K_{d}=570 \pm 338 \mathrm{nM}$, $B_{\max }=8.3 \pm 1.1 \mathrm{pmol} / \mathrm{mg}$ protein. Comparison of [ $\left.{ }^{3} \mathrm{H}\right] A M P A$ binding parameters in control mice and "nervous" mice (Table 1) shows a reduction in the low affinity $B_{\max }$ to $24 \%$ of control $(P<0.01)$ and a slight but non-significant decrease in the affinity of the high affinity binding site (Fig. 3A, B). In the granule cell layer of control mice, $\left[{ }^{3} \mathrm{H}\right]$ AMPA binding produced linear Scatchard plots with $K_{d}=40 \pm 3$ $\mathrm{nM}, B_{\max }=2.7 \pm 0.1 \mathrm{pmol} / \mathrm{mg}$ protein. Similarly, in the granule cell layer of Purkinje cell-deficient mice $\left[{ }^{3} \mathrm{H}\right]$ AMPA binding produced linear Scatchard plots resolved into a single class of binding sites with $K_{d}=61 \pm 7 \mathrm{nM}, \quad B_{\max }=2.3 \pm 0.1 \mathrm{pmol} / \mathrm{mg}$ protein

In control mice quisqualate-sensitive $\left[{ }^{3} \mathrm{H}\right]$ glutamate binding sites were almost two times as numerous in the molecular layer as they were in the granule cell layer ( $B_{\max }=16.9$ vs $10.0 \mathrm{pmol} / \mathrm{mg}$ protein; Fig. $2 \mathrm{C}$ ). Scatchard analysis revealed a single binding site in the molecular layer with $K_{d}=658 \pm 76 \mathrm{nM}$, $B_{\max }=16.9 \pm 9.5 \mathrm{pmol} / \mathrm{mg}$ protein. In "nervous" mutants, there was a marked loss of quisqualatesensitive $\left[{ }^{3} \mathrm{H}\right]$ glutamate binding sites in the molecular layer where the Purkinje cell dendrites are located. Saturation studies in these mice revealed a single class of binding sites with $K_{d}=842 \pm 82 \mathrm{nM}$, $B_{\max }=9.2 \pm 0.6 \mathrm{pmol} / \mathrm{mg}$ protein. Thus, there was a reduction in $B_{\max }$ to $54 \%$ of control $(P<0.01)$ in the molecular layer. Saturation analysis of quisqualatesensitive binding sites in the granule cell layer of control mice showed a single class of binding sites $K_{d}=1296 \pm 211 \mathrm{nM}, B_{\max }=10.0 \pm 1.0 \mathrm{pmol} / \mathrm{mg}$ protein. Quisqualate-sensitive $\left[{ }^{3} \mathrm{H}\right]$ glutamate binding sites were not significantly altered in the granule cell layer of "nervous" mice $K_{d}=799 \pm 146 \mathrm{nM}$, $B_{\max }=7.0 \pm 1.3 \mathrm{pmol} / \mathrm{mg}$ protein (Table 2).

$\left[{ }^{3} \mathrm{H}\right] \mathrm{CNQX}$, an ionotropic quisqualate receptor antagonist, revealed binding characteristics similar to

Table 1. Comparison of $\left[{ }^{3} \mathrm{H}\right] \mathrm{AMPA}$ binding parameters in the molecular layer of control mice and mice deficient in Purkinje cells ("nervous" mutant mice)

\begin{tabular}{lcccc}
\hline & $K_{\mathrm{H}}$ & $(\mathrm{nM})$ & $K_{\mathrm{L}}$ & \multicolumn{2}{c}{$B_{\max (\mathrm{H})}$} & $\begin{array}{c}B_{\max (\mathrm{L})} \\
(\mathrm{pmol} / \mathrm{mg}\end{array}$ \\
\hline protein $)$
\end{tabular}

Data represent the mean \pm S.E.M. of three separate experiments (three control and three "nervous" mutant mice) performed in Tris- $\mathrm{HCl}$ buffer containing $2.5 \mathrm{mM}$ $\mathrm{CaCl}_{2}$ and $100 \mathrm{mM} \mathrm{KSCN}$. $\mathrm{H}$ denotes high affinity and $\mathrm{L}$ denotes low affinity. Data were analysed by the LIGAND program. Two-site fits were significantly better than one-site fits in all cases. ${ }^{*} P<0.01$ by $F$-test. 

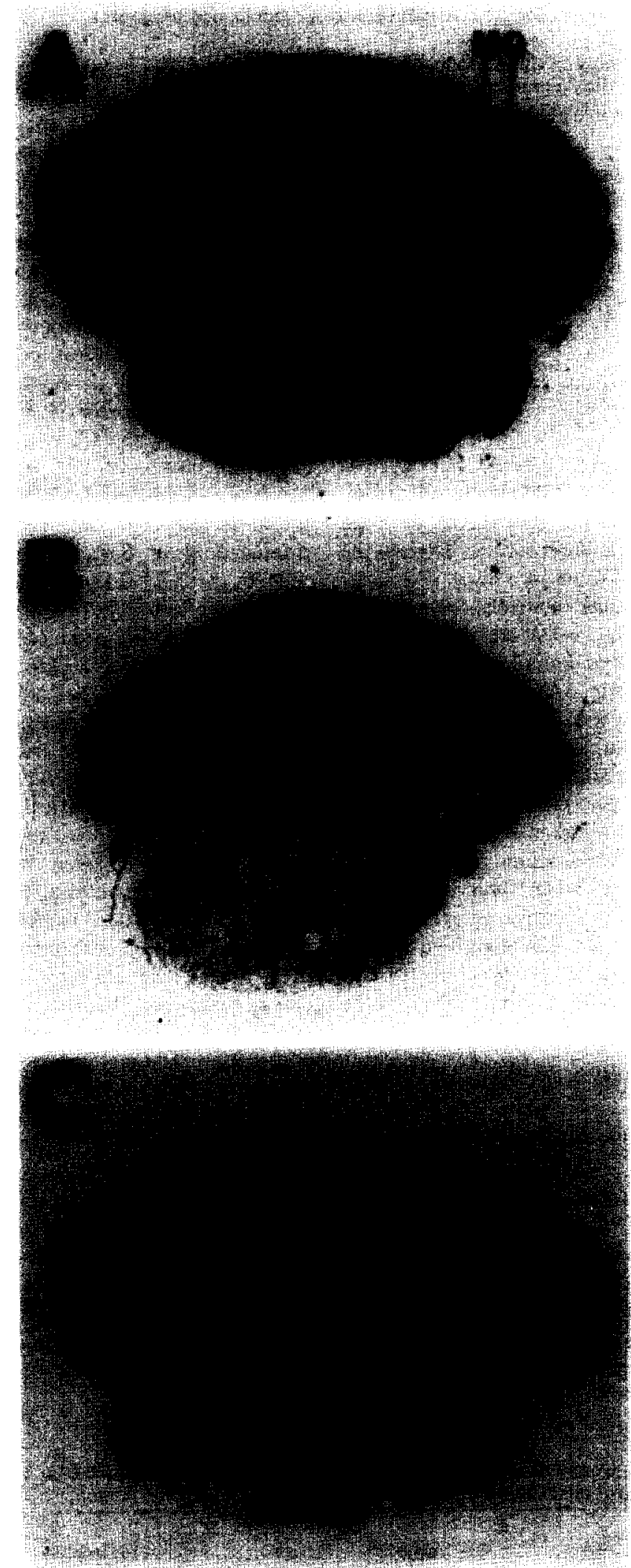

Fig. 1. Cresyl Violet-stained sections of control cerebellum (A), Purkinje cell-deficient "nervous" mutant cerebellum (B), and cerebellum rendered granuloprival by MAM treatment (C). In control cerebellum the granule cell layer $(G)$ is characterized by densely packed granule cell bodies. The Purkinje cells are arranged in a monolayer between the granule cell layer and the molecular layer. The molecular layer $(M)$ has relatively few intrinsic neurons and abundant neuropil consisting largely of granule cell axons and Purkinje cell dendrites. In Purkinje cell-deficient mice there were very few Purkinje cells. The granule cell layer appeared normal while the molecular layer was slightly thinner than normal. In granuloprival mice there was a marked depletion of granule cells in a patchy distribution. In affected areas, there was a decreased density of granule cell bodies. Purkinje cells appeared normal and the molecular layer was slightly narrower than in controls. 

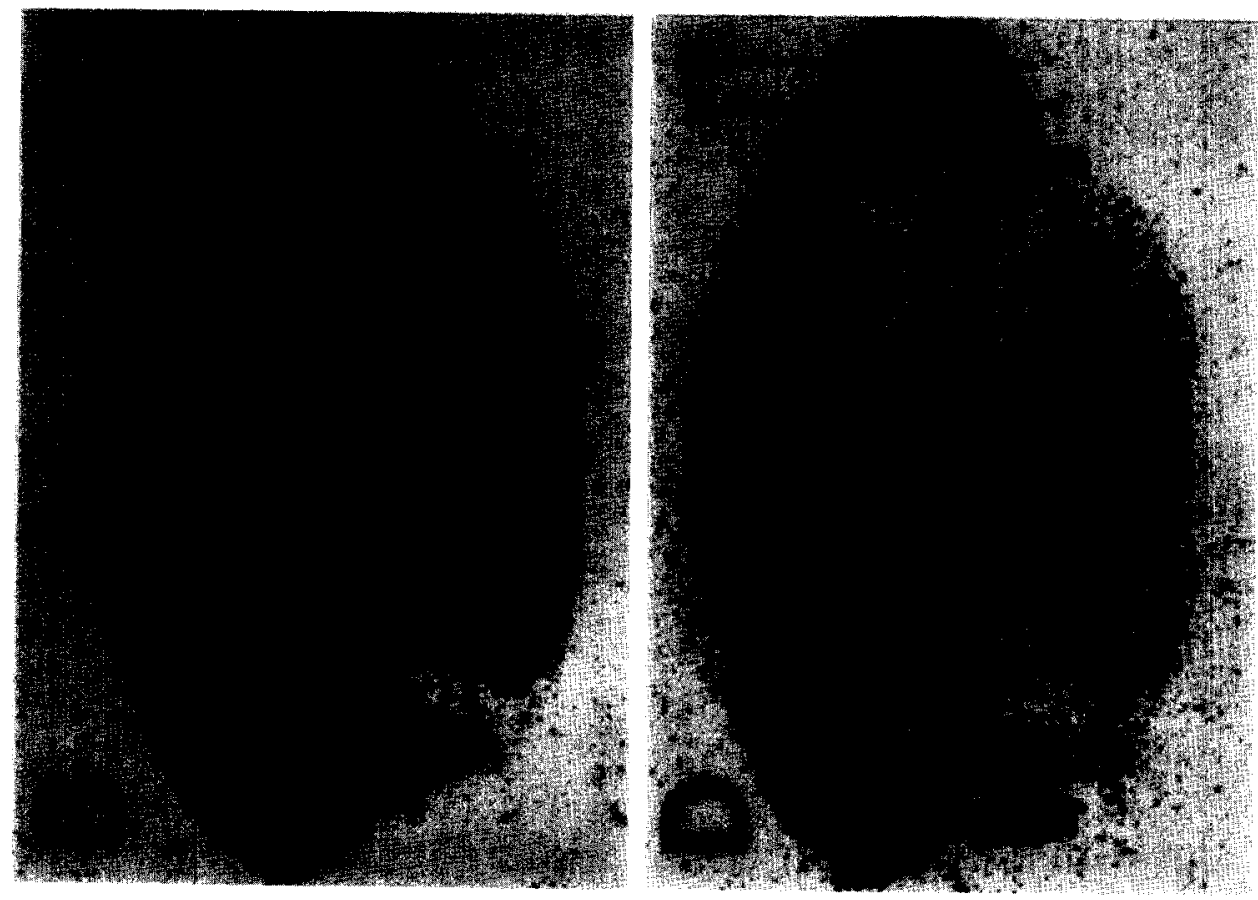

?ำ

要令

$<$

$\sum_{z}$ 氜 플 ใิ웜 吗
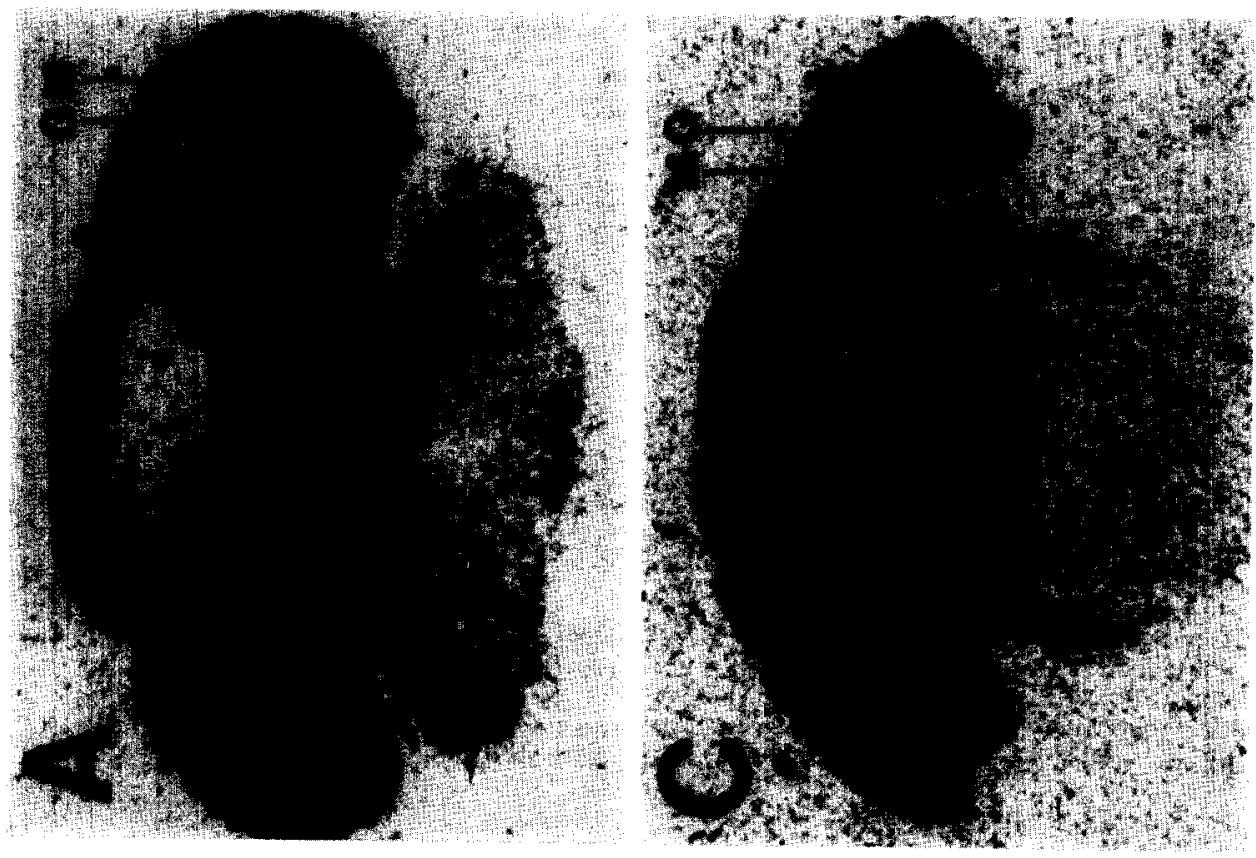

00 


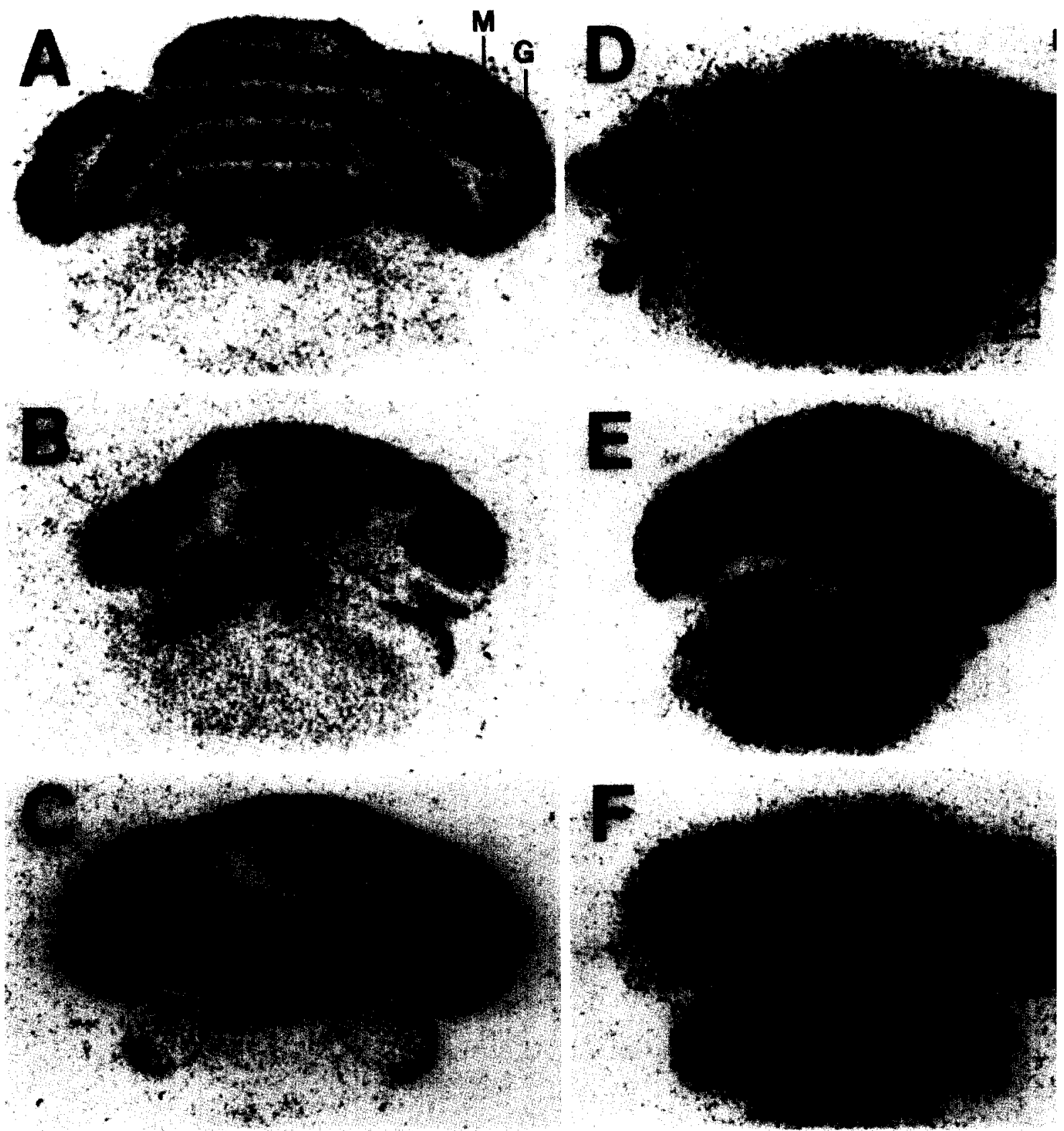

Fig. 3. Autoradiographs of $\left[{ }^{3} \mathrm{H}\right] A M P A$ binding $(A-C)$ and $\left[{ }^{3} \mathrm{H}\right]$ glycine binding $(D-F)$ in control cerebellum (A, D), Purkinje cell-deficient ("nervous" mutant) cerebellum (B, E), and granuloprival (MAM-treated) cerebellum (C, F). Although separate sets of controls were used for comparison with the Purkinje cell-deficient ("nervous") mice and the granuloprival (MAM-treated) mice, as described under Experimental Procedures, only the controls used in the Purkinje cell-deficient ("nervous" mutant) experiment are shown.

$\left[{ }^{3} \mathrm{H}\right] \mathrm{AMPA}$ (Fig. 2A, B). In control mice, when binding was done at $90 \mathrm{nM}\left[{ }^{3} \mathrm{H}\right] \mathrm{CNQX}$ there was more binding in the molecular layer than in the granule cell layer of cerebellum ( $9.9 \mathrm{vs} 1.7 \mathrm{pmol} / \mathrm{mg}$ protein) and there was a large decrease in binding in the molecular layer of "nervous" mice ( 9.9 vs $3.5 \mathrm{pmol} / \mathrm{mg}$ protein). $\left[{ }^{3} \mathrm{H}\right] \mathrm{CNQX}$ binding was reduced to $36 \%$ of control
$(P<0.01)$ in the molecular layer of "nervous" mutant mice while $\left[{ }^{3} \mathrm{H}\right] \mathrm{CNQX}$ binding was unchanged in the granule cell layer of these mice ( $1.7 \mathrm{vs}$ $1.5 \mathrm{pmol} / \mathrm{mg}$ protein; Table 2).

In contrast to the quisqualate receptor ligands, there was more NMDA-sensitive $\left[{ }^{3} \mathrm{H}\right]$ glutamate binding in the granule cell layer of control $(\mathrm{nr} /+)$ mice 


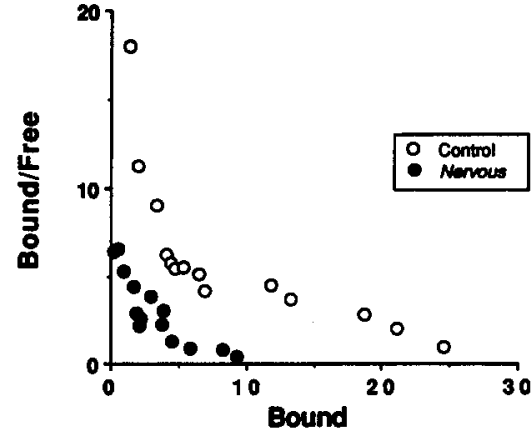

Fig. 4. Saturation analysis of $\left[{ }^{3} \mathrm{H}\right] \mathrm{AMPA}$ binding in the molecular layer of control (open circles) vs Purkinje celldeficient (closed circles) mice. These points are representative data from individual animals. AMPA binding produced curvilinear Scatchard plots which fit a two-site model better than a one-site model. There was a large significant $(P<0.01)$ decrease in the number of low affinity binding sites in the Purkinje cell deficient "nervous" mutant mouse with no change in the high affinity binding sites. See text for details.

than in the molecular layer $(0.15 \mathrm{vs} 0.02 \mathrm{pmol} / \mathrm{mg}$ protein; Fig. 2D). "Nervous" mutant mice had unchanged levels of NMDA binding in both the granule cell layer and the molecular layer (Table 2).

In control mice $\left[{ }^{3} \mathrm{H}\right] \mathrm{glycine}$ binding, which labels the glycine modulatory site associated with the NMDA receptor complex, ${ }^{3}$ paralleled NMDAsensitive binding in that there was more $\left[{ }^{3} \mathrm{H}\right]$ glycine binding in the granule cell layer than in the molecular layer $(1.2$ vs $0.1 \mathrm{pmol} / \mathrm{mg}$ protein; Fig. 3D). $\left[{ }^{3} \mathrm{H}\right]$ Glycine binding was not significantly changed in either the molecular layer or granule cell layer of "nervous" mice compared to heterozygote controls (Fig. 3D, E).

\section{Granuloprival mice and saline-injected controls}

In the molecular layer of granuloprival (MAMtreated) mouse cerebella, $\left[{ }^{3} \mathrm{H}\right] \mathrm{AMPA}$ binding (measured at a single concentration of $37 \mathrm{nM}$ ) was increased to $205 \%$ of control $(4.1 \mathrm{vs} 2.0 \mathrm{pmol} / \mathrm{mg}$ protein; $P<0.01$ ) in regions adjacent to severe granule cell depletion (Fig. $3 \mathrm{C}$ ). [ $\left.{ }^{3} \mathrm{H}\right] \mathrm{AMPA}$ binding was unchanged in the granule cell layer of these mice (Table 2). Quisqualate-sensitive $\left[{ }^{3} \mathrm{H}\right]$ glutamate binding was increased to $152 \%$ of control (2.6 vs $1.7 \mathrm{pmol} / \mathrm{mg}$ protein; $P<0.01$ ) in the molecular layer of these mice. Levels of quisqualate-sensitive $\left[{ }^{3} \mathrm{H}\right]$ glutamate binding were unchanged in the granule cell layer of these mice (Table 2). $\left[{ }^{3} \mathrm{H}\right] \mathrm{CNQX}$ binding was increased to $136 \%$ of control $(5.6 \mathrm{vs} 4.1 \mathrm{pmol} / \mathrm{mg}$ protein; $P<0.02$ ) in the molecular layer of granuloprival mice. $\left[{ }^{3} \mathrm{H}\right] \mathrm{CNQX}$ binding was unchanged in the granule cell layer of these mice. In areas where Cresyl Violet staining revealed severe granule cell depletion there was a marked reduction in both NMDAsensitive $\left[{ }^{3} \mathrm{H}\right]$ glutamate binding and in $\left[{ }^{3} \mathrm{H}\right]$ glycine binding. NMDA-sensitive $\left[{ }^{3} \mathrm{H}\right]$ glutamate binding was decreased to $68 \%$ of control (220 vs $150 \mathrm{fmol} / \mathrm{mg}$ protein; $P<0.01)$. $\left[{ }^{3} \mathrm{H}\right]$ Glycine binding was decreased to $59 \%$ of control $(730$ vs $430 \mathrm{fmol} / \mathrm{mg}$ protein; $P<0.01)$. In contrast, in areas where the granule cell layer was not affected by the MAM lesion levels of both NMDA-sensitive [ $\left.{ }^{3} \mathrm{H}\right]$ glutamate binding and $\left[{ }^{3} \mathrm{H}\right]$ glycine binding were unchanged

Table 2. Comparison of cerebellar excitatory amino acid binding sites in the molecular layer and granule cell layer of control, Purkinje cell-deficient ("nervous") and granuloprival (methylazoxymethanol-treated) mice

\begin{tabular}{|c|c|c|}
\hline & \multicolumn{2}{|l|}{ Assay } \\
\hline & $\begin{array}{l}\text { Purkinje cell-deficient } \\
\text { ( } \% \text { of control binding }\end{array}$ & $\begin{array}{l}\text { Granuloprival } \\
\pm \text { S.E.M.) }\end{array}$ \\
\hline $\begin{array}{l}\text { Molecular layer } \\
\left.\text { [ }{ }^{3} \mathrm{H}\right] \text { AMPA } \\
{\left[{ }^{3} \mathrm{H}\right] \mathrm{CNQX}} \\
\text { Quisqualate-sensitive }\left[{ }^{3} \mathrm{H}\right] \text { glutamate } \\
\text { NMDA-sensitive }\left[{ }^{3} \mathrm{H}\right] \text { glutamate } \\
{\left[{ }^{3} \mathrm{H}\right] \text { Glycine }}\end{array}$ & $\begin{array}{l}24 \pm 1^{*} \\
36 \pm 10^{*} \\
54 \pm 9^{*} \\
90 \pm 1 \\
65 \pm 26\end{array}$ & $\begin{array}{l}205 \pm 40^{*} \\
136 \pm 7^{* *} \\
149 \pm 16^{*} \\
94 \pm 1 \\
93 \pm 6\end{array}$ \\
\hline $\begin{array}{l}\text { Granule cell layer } \\
{\left[{ }^{3} \mathrm{H}\right] \mathrm{MPA}} \\
{\left[{ }^{3} \mathrm{H}\right] \mathrm{CNQX}} \\
\text { Quisqualate-sensitive }\left[{ }^{3} \mathrm{H}\right] \text { glutamate } \\
\text { NMDA-sensitive }\left[{ }^{3} \mathrm{H}\right] \text { glutamate } \\
{\left[{ }^{3} \mathrm{H}\right] \text { Glycine }}\end{array}$ & $\begin{array}{r}78 \pm 6 \\
87 \pm 30 \\
111 \pm 16 \\
114 \pm 14 \\
98 \pm 13\end{array}$ & $\begin{array}{r}106 \pm 14 \\
116 \pm 29 \\
131 \pm 44 \\
68 \pm 3^{*} \\
59 \pm 4^{*}\end{array}$ \\
\hline
\end{tabular}

Data are presented as percentage of control values \pm S.E.M. In these experiments separate sets of controls were used for comparison with the Purkinje cell-deficient ("nervous") mice and the granuloprival (MAM-treated) mice, as described under Experimental Procedures. Control values represent $100 \%$ in two separate sets of control animals. [ $\left.{ }^{3} \mathrm{H}\right] \mathrm{AMPA}$ and quisqualate-sensitive $\left[{ }^{3} \mathrm{H}\right]$ glutamate values for Purkinje cell-deficient mice were compared as $B_{\max }$ values from saturation studies. All other percentages reflect changes in specific binding at a single concentration of ${ }^{3} \mathrm{H}$ ligand. Levels of significance $\left({ }^{* *} P<0.02,{ }^{*} P<0.01\right.$ using unpaired $t$-tests) were determined by comparison with appropriate controls. 
from controls. Granuloprival mice had control levels of NMDA-sensitive $\left[{ }^{3} \mathrm{H}\right]$ glutamate binding and $\left[{ }^{3} \mathrm{H}\right]$ glycine binding in the molecular layer of cerebellum (Table 2).

\section{DISCUSSION}

\section{Nervous (Purkinje cell-deficient mice)}

Accumulated evidence suggests that L-glutamate is the endogenous EAA neurotransmitter at the parallel fiber-Purkinje cell synapse. 2,26,27,48 $^{\text {Biochemical data }}$ reveal that $\mathrm{L}$-glutamate is contained in parallel fibers, and that it is released in a calcium-dependent fashion. ${ }^{28,40}$ The parallel fiber-Purkinje cell synapse is the most numerous synapse in the molecular layer of cerebellum..$^{30}$ Autoradiographic binding studies have demonstrated previously that $75 \%$ of glutamate binding in the molecular layer of normal mice is associated with binding to quisqualate-sensitive sites. ${ }^{4}$ The correlation between the abundant parallel fiber-Purkinje cell synapses and the comparably abundant quisqualate-sensitive binding suggests that quisqualate receptors mediate glutamate responses at this synapse.

AMPA is thought to be a potent agonist at the quisqualate subclass of glutamate receptors linked to a cationic membrane channel. In agreement with previous binding studies, in the presence of thiocyanate, $\left[{ }^{3} \mathrm{H}\right]$ AMPA binding produced curvilinear Scatchard plots in the molecular layer of cerebellum which could be resolved into two binding sites. ${ }^{19,33}$ In the molecular layer of "nervous" mice lacking Purkinje cells there was a large decrease in the low affinity $\left[{ }^{3} \mathrm{H}\right]$ AMPA binding site (Table 1) but no change in the high affinity $\left[{ }^{3} \mathrm{H}\right] \mathrm{AMPA}$ binding. In contrast, saturation analysis of $\left[{ }^{3} \mathrm{H}\right] A$ MPA binding in the granule cell layer of cerebellum produced linear Scatchard plots indicating only high affinity sites and these sites did not change in "nervous" mice. Ligand binding studies utilizing $\left[{ }^{3} \mathrm{H}\right]$ AMPA have been complicated by the presence of high and low affinity binding sites and it is not known whether the low affinity or high affinity AMPA site revealed in ligand binding studies corresponds to the physiologically active receptor. In the present study, our Scatchard analyses indicate that the low affinity site appears to be specific to the Purkinje cells and may thus be the relevant receptor there (Fig. 4). Any remaining $\left[{ }^{3} \mathrm{H}\right]$ AMPA binding sites are probably located on the $10 \%$ of Purkinje cells unaffected by the "nervous" mutation or on remaining basket, stellate, and Golgi cells with which the parallel fibers also synapse.

Previously, it has been demonstrated that the regional correlation between levels of quisqualatesensitive $\left[{ }^{3} \mathrm{H}\right]$ glutamate binding and $\left[{ }^{3} \mathrm{H}\right]$ AMPA binding is excellent, but some differences do exist. ${ }^{34,35}$ Quisqualate-sensitive $\left[{ }^{3} \mathrm{H}\right]$ glutamate binding appears to label both the ionotropic quisqualate receptor and the metabotropic quisqualate receptor, whereas the more specific ligand AMPA labels only the ionotropic quisqualate receptor. ${ }^{5}$ AMPA may thus bind to a subset of quisqualate-sensitive receptors. Similar to published reports and in contrast to $\left[{ }^{3} \mathrm{H}\right] \mathrm{AMPA}$ binding, quisqualate-sensitive $\left[{ }^{3} \mathrm{H}\right]$ glutamate binding produced linear Scatchard plots in both the molecular layer and the granule cell layer. ${ }^{36}$ Competition studies indicate that glutamate has similar affinities for the ionotropic and metabotropic subtypes of quisqualate-sensitive $\left[{ }^{3} \mathrm{H}\right]$ glutamate binding. The large decrease in quisqualate-sensitive $\left[{ }^{3} \mathrm{H}\right]$ glutamate binding in the molecular layer of nervous mutant mice suggests that quisqualate receptors are located on cerebellar Purkinje cells, but quisqualate-sensitive $\left[{ }^{3} \mathrm{H}\right]$ glutamate binding does not differentiate between ionotropic and metabotropic receptor subtypes. Our data appear to suggest that more $\left[{ }^{3} \mathrm{H}\right] \mathrm{AMPA}$ binding sites exist in the molecular layer of cerebellum than quisqualate-sensitive $\left[{ }^{3} \mathrm{H}\right]$ glutamate binding sites. This observation may have resulted from our experimental design, since in the quisqualate-sensitive $\left[{ }^{3} \mathrm{H}\right]$ glutamate binding assay we used a single concentration of quisqualate $(2.5 \mu \mathrm{M})$ to determine nonspecific binding for all points in the saturation curve. This single concentration was likely to result in an underestimate of the proportion of $\left[{ }^{3} \mathrm{H}\right]$ glutamate binding which is quisqualate-sensitive, since the concentration of quisqualate needed to block $95 \%$ of the high affinity quisqualate sites increases as the concentration of $\left[{ }^{3} \mathrm{H}\right]$ glutamate is increased. Thus, we have likely underestimated the proportion of quisqualatesensitive $\left[{ }^{3} \mathrm{H}\right]$ glutamate binding present at high concentrations of $\left[{ }^{3} \mathrm{H}\right]$ glutamate. The present data are therefore inconclusive concerning the hypothesis that AMPA binding sites are a subset of all quisqualatesensitive glutamate binding sites. Nevertheless, we have recently suggested that there is an AMPAinsensitive component of quisqualate-sensitive $\left[{ }^{3} \mathrm{H}\right]$ glutamate binding which appears to label metabotropic quisqualate receptors. ${ }^{5}$ This AMPA-insensitive binding component is also decreased in nervous (nr/nr) mouse cerebella. ${ }^{5}$ It thus seems likely that both AMPA-sensitive (ionotropic) and AMPAinsensitive (metabotropic) quisqualate receptors are located on Purkinje cells. Quisqualate-sensitive $\left[{ }^{3} \mathrm{H}\right]$ glutamate binding sites are also found in the granule cell layer of cerebellar cortex. However, these sites are unchanged in mutant mice.

The binding of the potent competitive non-NMDA receptor antagonist $\left[{ }^{3} \mathrm{H}\right] \mathrm{CNQX}{ }^{18}$ correlates highly with the properties and distribution of $\left[{ }^{3} \mathrm{H}\right] \mathrm{AMPA}$ binding (Fig. 2A, B). ${ }^{21,35}$ Analysis of $\left[{ }^{3} \mathrm{H}\right] \mathrm{CNQX}$ binding in Purkinje cell-deficient mice was decreased to almost the same level as $\left[{ }^{3} \mathrm{H}\right]$ AMPA binding in the molecular layer of cerebellum but was not altered in the granule cell layer. The larger decrease in the binding of both ionotropic specific ligands (AMPA and CNQX) than in quisqualate-sensitive $\left[{ }^{3} \mathrm{H}\right]-$ glutamate binding (Table 2) may indicate that a larger percentage of cerebellar ionotropic receptors 
reside on Purkinje cells than metabotropic receptors. As reported previously, in the cerebellar cortex NMDA-sensitive $\left[{ }^{3} \mathrm{H}\right]$ glutamate binding is more abundant in the granule cell layer than in the molecular layer (Fig. 2D). ${ }^{14,36}$ These binding sites in the granule cell layer may be located on the granule cells themselves as they are the target of excitatory input from mossy fibers, and based on immunocytochemical data, the mossy fibers may be glutamatergic. ${ }^{.}$In Purkinje cell-deficient mutant mice, NMDA binding sites were unchanged in the molecular layer of cerebellar cortex. This evidence suggests that few, if any, NMDA binding sites are located on Purkinje cell dendrites and further strengthens the supposition that quisqualate receptors mediate excitatory transmission at the parallel fiber-Purkinje cell synapse. It is likely that binding to NMDA receptors in the molecular layer is localized to stellate cells and possibly to basket and Golgi cells: this is in agreement with electrophysiological studies in which NMDA has prominent effects on inhibitory interneurons when applied iontophoretically., ${ }^{7,38}$

In agreement with this, $\left[{ }^{3} \mathrm{H}\right]$ glycine binding, which presumably binds to the glycine site associated with the NMDA receptor complex, mimics the NMDA binding results (Fig. 3A). These binding data, in conjunction with electrophysiological and neurotoxicity studies, further suggest that the NMDA receptor complex is not localized to Purkinje cells. ${ }^{7,11,13,17}$

\section{Granuloprival mice}

It has been shown previously in both homogenate and autoradiographic studies that $\left[{ }^{3} \mathrm{H}\right]$ glutamate binding increases following neonatal MAM treatment in mouse cerebella. ${ }^{36,43}$ We have also found that when Purkinje cells are deafferentated by granule cell damage in MAM-treated mice there is an increase in quisqualate-specific $\left[{ }^{3} \mathrm{H}\right]$ glutamate binding in areas of the molecular layer adjacent to the regions of greatest granule cell ablation. Although we cannot rule out that the increase in receptor density is merely an effect of an enriched concentration of Purkinje cell dendrites in a parallel fiber-deficient area, it is noteworthy that Slevin et al. found a $70 \%$ increase in the binding of $\left[{ }^{3} \mathrm{H}\right]$ glutamate (under non-selective binding conditions) even when accounting for changes in loss of cerebellar mass. ${ }^{43,47}$ By utilizing the anatomical resolution possible with receptor autoradiography and ligands selective for glutamate receptor subtypes we found the increase in glutamate receptors to be localized to the molecular layer of cerebellum and to be of the quisqualate type. Due to the deficiency of granule cell glutamatergic input and the preservation of normal postsynaptic dendritic spines on the Purkinje cells of granuloprival mice, it may be postulated that the increase in quisqualate receptor-specific ligand binding reflects an actual up-regulation of receptors on the surviving neurons. The up-regulation hypothesis seems likely to be due to the specificity of the binding sites being increased. Only assays of the quisqualate receptor-specific ligands (quisqualate-sensitive $\left[{ }^{3} \mathrm{H}\right]$ glutamate, $\left[{ }^{3} \mathrm{H}\right] \mathrm{AMPA}$, and $\left[{ }^{3} \mathrm{H}\right] \mathrm{CNQX}$ ) showed increases in areas of the molecular layer directly adjacent to severe granule cell ablation. If the increase in glutamate binding sites was due to a concentrating effect then all glutamate receptor binding sites would be expected to increase. This was not the case since the two NMDA-specific ligands (NMDA-sensitive $\left[{ }^{3} \mathrm{H}\right]$ glutamate and $\left[{ }^{3} \mathrm{H}\right]$ glycine) revealed no significant changes in binding in either layer of the cerebellar cortex of granuloprival mice. Furthermore, previous reports indicated that $\left[{ }^{3} \mathrm{H}\right] \mathrm{kainate}$ binding sites are unchanged by this treatment. ${ }^{36}$

While the trend for the quisqualate receptorspecific ligands in the granuloprival mouse cerebellum is consistent, considerable variation in the degree of increased binding exists. There are both methodological and physiological explanations which could explain this difference. Methodologically, the data on the granuloprival cerebellum were obtained at single ligand concentrations and thus do not differentiate a relative change in receptor number or affinity. However, both Olson et al..$^{36}$ and Slevin et al. ${ }^{43}$ have reported saturation studies in MAM-treated mouse cerebella that suggest only a change in receptor number and not in the affinity of glutamate binding sites. More likely, the discrepancy reflects the complexity of quisqualate receptors themselves. Not only is it possible that two classes of quisqualate receptors exist (ionotropic and metabotropic), it has been proposed that the ionotropic quisqualate receptor itself has dual affinity states. ${ }^{19}$

We have provided evidence that three receptor ligands can be used to label quisqualate-specific EAA binding sites: quisqualate-sensitive $\left[{ }^{3} \mathrm{H}\right]$ glutamate binding, $\left[{ }^{3} \mathrm{H}\right]$ AMPA binding, and $\left[{ }^{3} \mathrm{H}\right] \mathrm{CNQX}$ binding. Although the changes observed with the different ligands were not identical, the direction of the changes correlated well in the Purkinje cell-deficient ("nervous" mutants) and granuloprival (MAMtreated) mouse cerebella studied here. Thus, we have provided new and corroborative evidence that suggests that quisqualate receptors, measured with three different ligands, localize to the dendrites of cerebellar Purkinje cells and can up-regulate in response to deafferentation. Also, we have demonstrated that both NMDA and glycine receptor populations are located predominantly in the granule cell layer and that they are probably not present on Purkinje cells in the molecular layer in adult mice. Finally, the present data suggest that the low affinity AMPA binding site may be the component of AMPA binding which corresponds to the physiologically relevant receptor.

Acknowledgements - We gratefully appreciate the photographic assistance of Kevin O'Mara, the technical assistance of Zane Hollingsworth, and the advice of J. M. M. Olson. This work was supported by USPHS grant NS 19613 and 5T32 GM07863. 


\section{REFERENCES}

1. Beitz A. J., Larson A. A., Monaghan P., Altschuler R. A., Mullett M. M. and Madl J. E. (1986) Immunohistochemical localization of glutamate, glutaminase and aspartate aminotransferase in neurons of the pontine nuclei of the rat. Neuroscience 17, 741-753.

2. Blackstone C. D., Supattapone S. and Snyder S. H. (1989) Inositol phospholipid-linked glutamate receptors mediate cerebellar parallel fiber-Purkinje cell synaptic transmission. Proc. natn. Acad. Sci. U.S.A. 86, 4316-4320.

3. Bowery N. G. (1987) Glycine-binding sites and NMDA receptors in brain. Nature 326, 338-339.

4. Cha J. J., Greenamyre J. T., Nielsen E. Ø., Penney J. B. and Young A. B. (1988) Properties of quisqualate-sensitive $\mathrm{L}-\left[^{3} \mathrm{H}\right] \mathrm{glutamate}$ binding sites in rat brain as determined by quantitative autoradiography. $J$. Neurochem. $51,469-478$.

5. Cha J. J., Makowiec R. L., Penney J. B. and Young A. B. (1990) L- $\left[{ }^{3}\right.$ H]Glutamate labels the metabotropic excitatory amino acid receptor in rodent brain. Neurosci. Lett. 113, 78-83.

6. Chen S. and Hillman D. E. (1989) Regulation of granule cell number by a predetermined number of Purkinje cells in development. Devl Brain Res. 45, 137-147.

7. Crepel F., Dhanjal S. S. and Sears T. A. (1982) Effect of glutamate, aspartate and related derivatives on cerebellar Purkinje cell dendrites in the rat: an in vitro study. J. Physiol. 329, 297-317.

8. Fonnum F. (1984) Glutamate: a neurotransmitter in mammalian brain. J. Neurochem. 42, 1-11.

9. Foster A. C. and Fagg G. E. (1984) Acidic amino acid binding sites in mammalian neuronal membranes: their characteristics and relationship to synaptic receptors. Brain Res. Rev. 7, 103-164.

10. Freeman M. E., Lane J. D. and Smith J. E. (1983) Turnover rates of amino acid neurotransmitters in regions of rat cerebellum. J. Neurochem. 40, 1441-1447.

11. Garthwaite G. and Garthwaite J. (1984) Differential sensitivity of rat cerebellar cells in vitro to the neurotoxic effects of excitatory amino acid analogues. Neurosci. Lett. 48, 361-367.

12. Garthwaite J. and Brodbelt A. R. (1989) Synaptic activation of $N$-methyl-D-aspartate and non- $N$-methyl-D-aspartate receptors in the mossy fibre pathway in adult and immature rat cerebellar slices. Neuroscience 29, 401-412.

13. Garthwaite J., Garthwaite G. and Hajos F. (1986) Amino acid neurotoxicity: relationship to neuronal depolarization in rat cerebellar slices. Neuroscience 18, 449-460.

14. Greenamyre J. T., Olson J. M. M., Penney J. B. and Young A. B. (1985) Autoradiographic characterization of $N$-methyl-D-aspartate, quisqualate- and kainate-sensitive glutamate binding sites. J. Pharmac. exp. Ther. 233, $254-263$.

15. Greenamyre J. T., Young A. B. and Penney J. B. (1984) Quantitative autoradiographic distribution of L- $\left[{ }^{3} \mathrm{H}\right]$ glutamatebinding sites in rat central nervous system. $J$. Neurosci. 4, 2133-2144.

16. Hausmann B., Mangold U., Sievers J. and Berry M. (1985) Derivation of cerebellar Golgi neurons from the external granular layer: evidence from explantation of external granule cells in vivo. J. comp. Neurol. 232, 511-522.

17. Hirano T. and Hagiwara S. (1988) Synaptic transmission between rat cerebellar granule and Purkinje cells in dissociated cell culture: effects of excitatory-amino acid transmitter antagonists. Proc. natn. Acad. Sci. U.S.A. 85, 934-938.

18. Honore T., Davies S. N., Drejer J., Fletcher E. J., Jacobsen P., Lodge D. and Nielsen F. E. (1988) Quinoxalinediones: potent competitive non-NMDA glutamate receptor antagonists. Science 241, 701-703.

19. Honore T. and Drejer J. (1988) Chaotropic ions affect the conformation of quisqualate receptors in rat cortical membranes. $J$. Neurochem. 51, 457-461.

20. Honore T., Lauridsen J. and Krogsgaard-Larsen P. (1982) The binding of $\left[{ }^{3} \mathrm{H}\right] A M P A$, a structural analogue of glutamic acid to rat brain membranes. $J$. Neurochem. 38, 173-178.

21. Honore T., Nielsen E. $\varnothing$. and Drejer J. (1988) Molecular aspects of non-NMDA receptors based on the analysis of ${ }^{3} \mathrm{H}-\mathrm{AMPA},{ }^{3} \mathrm{H}-\mathrm{kainate}$ and ${ }^{3} \mathrm{H}-\mathrm{CNQX}$ (FG-9065) binding. In Frontiers in Excitatory Amino Acid Research (eds Cavalheiro E. A., Lehmann J. and Turski L.), pp. 39-46. Alan R. Liss, New York.

22. Hudson D. B., Valcana T., Bean G. and Timiras P. S. (1976) Glutamic acid: a strong candidate as the neurotransmitter of the cerebellar granule cell. Neurochem. Res. 1, 73-81.

23. Ito M. (1984) The Cerebellum and Neural Control. Raven Press, New York.

24. Johnston M. V. and Coyle J. T. (1982) Cytotoxic lesions and the development of transmitter systems. Trends Neurosci. 5, $153-156$.

25. Jones M. Z. and Gardner E. (1976) Pathogenesis of methylazoxymethanol-induced lesions in the postnatal mouse cerebellum. J. Neuropath. exp. Neurol. 35, 413-444.

26. Kano M. and Kato M. (1987) Quisqualate receptors are specifically involved in cerebellar synaptic plasticity. Nature 325, 276-279.

27. Kano M., Kato M. and Chang H. S. (1988) The glutamate receptor subtype mediating parallel fibre-Purkinje cell transmission in rabbit cerebellar cortex. Neurosci. Res. 5, 325-337.

28. Levi G., Gordon R. D., Gallo V., Wilkin G. P. and Balązs R. (1982) Putative acidic amino acid transmitters in the cerebellum. I. Depolarization-induced release. Brain Res. 239, 425-445.

29. Maragos W. F., Penney J. B. and Young A. B. (1988) Anatomic correlation of NMDA and ${ }^{3}$ H-TCP-labeled receptors in rat brain. $J$. Neurosci. 8, 493-501.

30. Martin J. H. (1989) Neuroanatomy Text and Atlas. Elsevier, New York.

31. Monaghan D. T., Holets V. R., Toy D. W. and Cotman C. W. (1983) Anatomical distributions of four pharmacologically distinct ${ }^{3} \mathrm{H}-\mathrm{L}$-glutamate binding sites. Nature $306,176-179$.

32. Munson P. J. (1985) LIGAND, a computerized analysis of ligand binding data. Meth. Enzym. 92, 543-575.

33. Murphy D. E., Snowhill E. W. and Williams M. (1987) Characterization of quisqualate recognition sites in rat brain tissue using D,L- $\left[{ }^{3} \mathrm{H}\right]$ alpha-amino-3-hydroxy-5-methylisoxazole-4-propionic acid (AMPA) and a filtration assay. Neurochem. Res. 12, 775-782.

34. Nielsen E. Ø., Cha J. J., Honore T., Penney J. B. and Young A. B. (1988) Thiocyanate stabilizes AMPA binding to the quisqualate receptor. Eur. J. Pharmac. 157, 197-203.

35. Nielsen E. Ø., Drejer J., Cha J. J., Young A. B. and Honore T. (1990) Autoradiographic characterization and localization of quisqualate binding sites in rat brain using the antagonist $\left[{ }^{3} \mathrm{H}\right] \mathrm{CNQX}$ : comparison with [ $\left.{ }^{3} \mathrm{H}\right] \mathrm{AMPA}$ binding sites. J. Neurochem. 54, 686-695.

36. Olson J. M. M., Greenamyre J. T., Penney J. B. and Young A. B. (1987) Autoradiographic localization of cerebellar excitatory amino acid binding sites in the mouse. Neuroscience 22, 913-923. 
37. Pan H. S., Frey K. A., Young A. B. and Penney J. B. Jr (1983) Changes in [ $\left.{ }^{3} \mathrm{H}\right]$ muscimol binding in substantia nigra, entopeduncular nucleus, globus pallidus, and thalamus after striatal lesions as demonstrated by quantitative receptor autoradiography. J. Neurosci. 3, 1189-1198.

38. Quinlan J. E. and Davies J. (1985) Excitatory and inhibitory responses of Purkinje cells in the rat cerebellum in vivo induced by excitatory amino acids. Neurosci. Lett. 60, 39-46.

39. Rea M. A., McBride W. J. and Rohde B. H. (1980) Regional and synaptosomal levels of amino acid neurotransmitters in the 3-acetylpyridine deafferentated rat cerebellum. J. Neurochem. 34, 1106-1108.

40. Sandoval M. E. and Cotman C. W. (1978) Evaluation of glutamate as a neurotransmitter of cerebellar parallel fibers. Neuroscience 3, 199-206.

41. Sidman R. L. and Green M. C. (1970) "Nervous", a new mutant mouse with cerebellar disease. In Les Mutants Pathologiques chez l'Animal Leur Interet dans la Recherche Biomedicale (ed. Sabourdy M.). Center National de la Recherche Scientifique, Paris.

42. Sladeczek F., Recasens M. and Bockaert J. (1988) A new mechanism for glutamate receptor action: phosphoinositide hydrolysis. Trends Neurosci. 11, 545-549.

43. Slevin J. T., Johnston M. V., Biziere K. and Coyle J. T. (1982) Methylazoxymethanol acetate ablation of mouse cerebellar granule cells: effects on synaptic neurochemistry. Devl Neurosci. 5, 3-12.

44. Sugiyama H., Ito I. and Hirono C. (1987) A new type of glutamate receptor linked to inositol phospholipid metabolism. Nature 325, 531-533.

45. Watkins J. C. and Evans R. H. (1981) Excitatory amino acid transmitters. A. Rev. Pharmac. Toxic. 21, $165-204$.

46. Wiklund L., Toggenburger G. and Cuenod M. (1982) Aspartate: possible neurotransmitter in cerebellar climbing fibers. Science 216, 78-80.

47. Woodward D. J., Bickett D. and Chanda R. (1975) Purkinje cell dendritic alterations after transient developmental injury of the external granular layer. Brain Res. 97, 195-214.

48. Young A. B., Oster-Granite M. L., Herndon R. M. and Snyder S. H. (1974) Glutamic acid: selective depletion by viral-induced granule cell loss in hamster cerebellum. Brain Res. 73, 1-13. 